\title{
PHYSICAL-CHEMICAL PROCESSES AND PATTERNS OF DIVERSITY OF THE CHILEAN EASTERN BOUNDARY PELAGIC AND BENTHIC MARINE ECOSYSTEMS: AN OVERVIEW
}

\author{
PROCESOS FISICO-QUIMICOS Y PATRONES DE DIVERSIDAD DE \\ ECOSISTEMAS MARINOS CHILENOS PELAGICOS Y BENTONICOS: UNA \\ REVISION
}

\author{
Rubén Escribano ${ }^{1}$, Miriam Fernández ${ }^{2}$ \& Antonio Aranís ${ }^{3}$ \\ ${ }^{1}$ Center for Oceanographie Research in the Eastern South Pacific (COPAS), Departamento de Oceanografía, Facultad \\ de Recursos Naturales y Oceanografía, Universidad de Concepción, Estación de Biología Marina, P.O. Box 42, \\ Dichato, Chile. Email: rescribano@udec.cl \\ ${ }^{2}$ Center for Advanced Studies in Ecology and Biodiversity and Coastal Marine Research Station, Departamento de \\ Ecología, Pontificia Universidad Católica de Chile, Casilla 114-D, Santiago, Chile. \\ ${ }^{3}$ Instituto de Fomento Pesquero, Blanco 839, Valparaíso, Chile.
}

\begin{abstract}
The biological diversity of the Chilean marine ecosystem (CME) has recently become an issue of interest to Chilean scientists and authorities concerned about the impact of human activities and ongoing climate change on the structure, functioning, and sustainable use of this large marine region, recognized as one of the most productive ecosystems of the world's is oceans. In this paper, the available information is examined in order to describe the major environmental characteristics of the CME and its associated flora and fauna, both in the benthic and pelagic systems, with the main goal of identifying environmental discontinuities and boundaries which may serve to define biogeographical units and characterize their biodiversity patterns. Physical and chemical processes are also described. In the pelagic system, three major regions may be identified: (1) the Northern Upwelling Region $\left(18^{\circ}-30^{\circ} \mathrm{S}\right)$, (2) the Central/Southern Upwelling Region $\left(30^{\circ}-42^{\circ} \mathrm{S}\right)$, and (3) the Austral Fjords Region $\left(42^{\circ}-55^{\circ} \mathrm{S}\right)$. These could be defined as biogeographical units, though biodiversity patterns may still require further analyses. For the benthic system, two major provinces are distinguished: the Peru-Chile province (from Paita in Peru to Valparaíso in Chile) and the Magellanic province (Chiloé Island to Cape Horn). A clear transition zone at about $30^{\circ} \mathrm{S}$ has also been described. The limits of these biogeographical regions, however, are not fixed and may vary seasonally and interannually. Diversity patterns, as well as dominant and key species inhabiting these biogeographic compartments, are described on the basis of the available data. The studies now required to obtain better information to describe diversity and to identify the underlying processes are stressed, as well as the needs for initiating large scale and long-term programs for monitoring species and processes in the CME that may allow future analyses of diversity patterns along the Chilean coast for conservation purposes.
\end{abstract}

KeYwords: Biodiversity, benthic, Chilean marine ecosystem, conservation, pelagic.

\section{RESUMEN}

La diversidad biológica del ecosistema marino de Chile (CME) es un tema de alto interés para los científicos y autoridades de Chile, dada la actual preocupación por el impacto que las actividades humanas y los cambios climáticos pudieran tener sobre la estructura, funcionamiento y sustentabilidad de la productividad de esta gran región marina, reconocida como una de las más productivas del océano mundial. En el presente trabajo hemos examinado la información disponible con el objeto de describir las características ambientales más importantes del CME, así como su flora y fauna, tanto en el sistema bentónico como pelágico, con una meta esencial dirigida a la identificación de discontinuidades y barreras ambientales, las cuales pueden servir para definir unidades biogeográficas, y así caracterizar patrones de biodiversidad. Los principales procesos físicos y químicos también son descritos. En el sistema pelágico identificamos tres regiones 
mayores: (1) La región norte de surgencia $\left(18^{\circ}-30^{\circ} \mathrm{S}\right)$, (2) La región centro/sur de surgencia $\left(30^{\circ}-42^{\circ} \mathrm{S}\right)$, y (3) La región austral de fiordos $\left(42^{\circ}-55^{\circ} \mathrm{S}\right)$. Estas regiones podrían ser definidas como unidades biogeográficas, aunque sus patrones de biodiversidad pueden aún necesitar análisis adicionales. Para el sistema bentónico dos provincias mayores son distinguibles: la provincia Perú-Chile (desde Paita en Perú a Valparaíso en Chile), y la provincia Magallánica (Isla de Chiloé a Cabo de Hornos). Una clara zona de transición alrededor de los $30^{\circ} \mathrm{S}$ también ha descrito. Los límites de estas regiones biogeográficas no son sin embargo fijos, y pueden variar estacionalmente y entre años. Los patrones de diversidad, así como las especies dominantes y claves que habitan estos compartimentos biogeográficos son descritos sobre la base de datos disponibles. Los estudios necesarios para obtener información más robusta para describir la diversidad y los procesos que la sustentan son enfatizados, así como la necesidad de iniciar programas de monitoreo y procesos en el CME de gran escala y largo término, que puedan permitir futuros análisis de patrones de biodiversidad a lo largo de la costa chilena para propósitos de conservación.

Palabras claves: Biodiversidad, sistema bentónico, ecosistema marino de Chile, conservación, sistema pelágico.

\section{INTRODUCTION}

Biological diversity has become an issue of worldwide scientific interest in the last few decades, due to the increasing threats on the survival of certain living species and genetic variability (Purvis \& Hector 2000). According to the 1993 Convention on biological diversity (Glowka 1994), human activities are the major factors affecting the distribution and abundance of living organisms, producing important effects on diversity at the genetic, species, and ecosystem levels. Biological diversity may be affected by the use and exploitation of biotic resources, the loss and deterioration of habitats, pollution, species invasion (Carlton \& Geller 1993, Kennedy et al. 2002), and the introduction of exotic species (Bellorín \& Oliveira 2001). Further concerns have lately emerged from indications of the ongoing global climate change which could have unforeseen consequences by altering ecosystem structure and functioning, and hence, species diversity on a world scale (Globec Report 1999).

Marine ecosystems are the largest habitats subjected to threats on biological diversity. The world s oceans are the main reservoir of carbon and their key role, regulating the climate system, may strongly depend upon biogeochemical cycling, which can be modulated by the structure of the marine ecosystem. Yet, our knowledge of biological diversity and natural ecosystem functioning over large regions of the world's oceans is poor (Longhurst 1998). Moreover, the effects of different types of human activity on ecosystem dynamics and diversity have rarely been quantified. The south-eastern Pacific Ocean is not an exception to this worldwide situation. In spite of the existence of high quality information about the critical factors affecting the dynamics of the pelagic (e.g. González et al. 1998, Ulloa et al. 2001) and benthic (e.g. Gallardo 1977, Castilla 1979, Santelices 1980) marine communities of Chile, more is urgently needed to fully understand one of the most productive marine ecosystems in the world's oceans (Mann \& Lazier 1991). The large marine ecosystem (sensu Sherman et al. 1995) of the southeastern Pacific Ocean sustains major pelagic and benthic fisheries along the coast of Chile, an explosion in the aquaculture industry (mostly non-native species), and a growing use of coastal areas for different types of human activity. This increasing exploitation of the coastal ocean has not been accompanied by renewed efforts to increase our knowledge of the diversity of the marine biota and the identification of the processes maintaining diversity. Most of what is known about large scale patterns of diversity in Chile is based largely on past research expeditions along the coast and in offshore waters. The compilation of this information has provided basic taxonomic inventories in which many species have been identified and listed (see Antezana \& Bahamonde 2002, Lancellotti \& Vásquez 2000 for historical reviews). More recent studies have mostly focused on particular geographical areas, and in many cases, on particular target species. Thus, the biological communities of vast regions have not yet received proper attention. Modern molecular techniques for assessing biological diversity have been little used, except for a few exploited or ecologically important species (Castilla et al. 2002). Furthermore, the processes and mechanisms that help maintain biological diversity in this ecosystem have hardly been identified, and thus, are poorly understood. 
Gayana 67(2), 2003

The general goal of this review was to provide a broad account of what is known and what is unknown about the biological diversity of the Chilean marine ecosystem (CME) focusing on: (1) existing information that allows the description of diversity patterns, (2) key processes that may maintain bio- logical diversity in this large marine biome, and (3) the urgent need to increase our knowledge of the biodiversity of the south-eastern Pacific Ocean along the coast of Chile, with the final aim of defining a sound conservation plan for the CME. Both the benthic and pelagic systems are discussed.

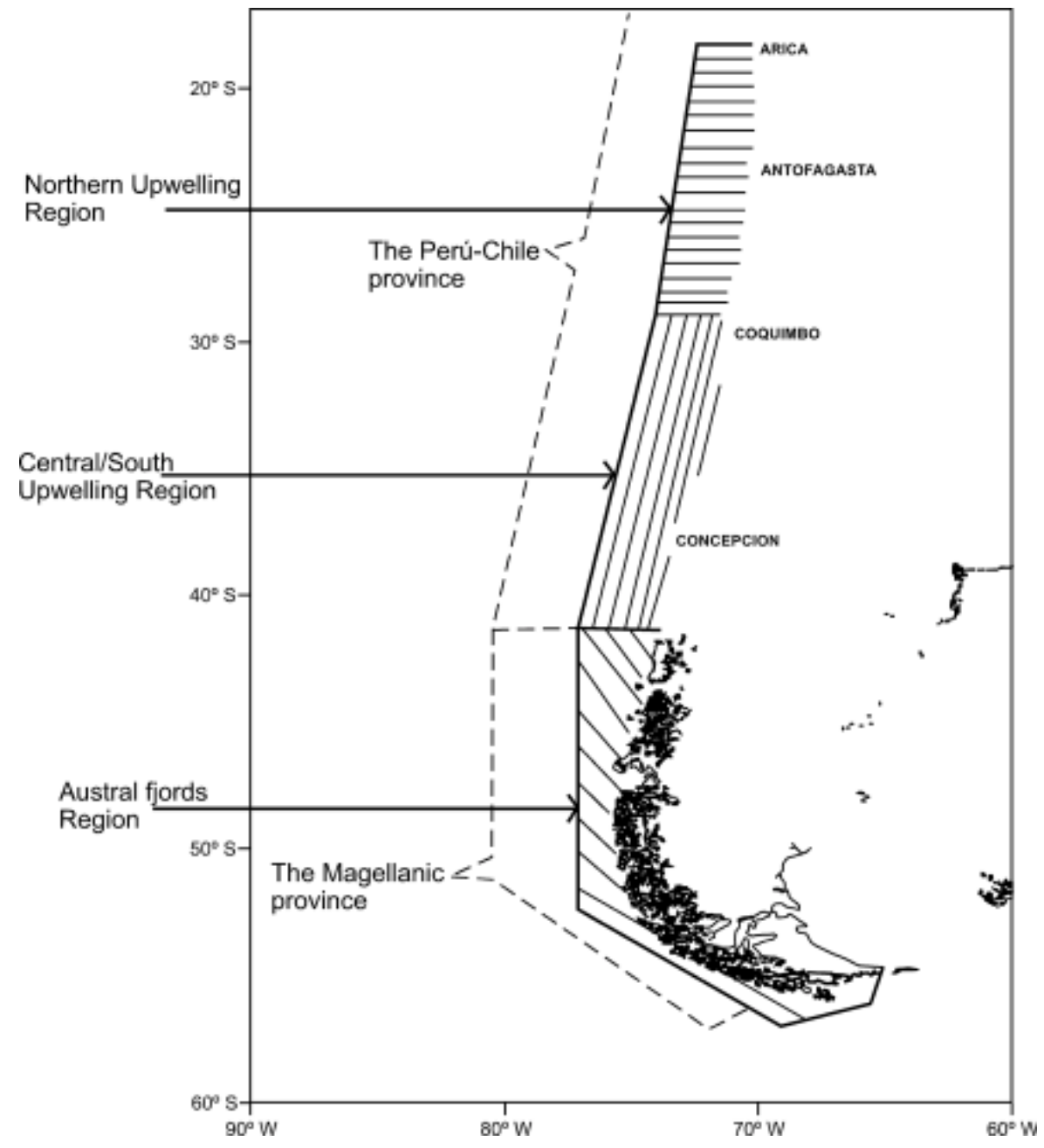

FIgURE 1. Biogeographical units of the Chilean marine ecosystem. The northern and central/southern upwellings and austral fjord regions define zones separated by oceanographic discontinuities and distinct biological characteristics of the pelagic system. The Peru-Chile and Magellanic provinces are suggested as biogeographical compartments for the benthic system.

FIGURA 1. Unidades biogeográficas del ecosistema marino chileno. Las regiones norte, centro/sur, y austral de fiordos definen zonas separadas por discontinuidades oceanográficas y características biológicas distintivas del sistema pelágico. Las provincias Perú-Chile y Magallánica se sugieren como compartimentos biogeográficos para el sistema bentónico. 
THE PHYSICAL AND CHEMICAL CHARACTERISTICS OF THE CME

The physical and chemical characteristics of the coastal waters off Chile are extremely diverse due to the interaction of very distinct water masses. For most purposes, four water masses can be distinguished: Subtropical Surface Water (STSW), Subantarctic Water (SAW), Antarctic Intermediate Water (AAIW), and Equatorial Subsurface Water (ESSW) (reviewed by Strub et al. 1998). Winddriven coastal upwelling (between 18 and $40^{\circ} \mathrm{S}$ ) brings the ESSW to the surface in the coastal zone, causing a persistent shallow oxygen minimum zone (OMZ) which, nearshore, can even be within the euphotic layer (<50 m) (Morales et al. 1996a). The OMZ $\left(<0.5 \mathrm{ml} \mathrm{O}_{2} \mathrm{~L}^{-1}\right)$ is a feature of an extensive part of the Chilean coast that raises interesting questions about the biogeochemical processes taking place within this suboxic environment and the role that it may play in limiting the vertical distribution and influencing the adaptation of planktonic assemblages.

The Chilean coast is aligned roughly north-south from $18^{\circ}$ to about $55^{\circ} \mathrm{S}$. The environment ranges from subtropical in the north, to temperate at midlatitudes, and a fjords-subantarctic region in the south. Bearing in mind the variable nature of oceanographic boundaries in the ocean and, considering as oceanographic discontinuities the tropical convergence (ca. $30^{\circ} \mathrm{S}$ ) and the division of the West Wind Drift (WWD into the equatorward Humboldt Current and the poleward Cape Horn Current (about $40^{\circ}-45^{\circ} \mathrm{S}$ ), 3 regions of the pelagic realm of the CME may be identified: (1)The northern upwelling region (NUR), (2) the central/ south upwelling region (CSUR), and (3) the austral fjords region (AFR) (Fig.1).

The upwelling zones in the north $\left(18^{\circ}-30^{\circ} \mathrm{S}\right)$ and central/southern $\left(30^{\circ}-45^{\circ} \mathrm{S}\right)$ regions are considered to be among the most productive eastern boundary systems in the world (Walsh 1991, Mann \& Lazier 1991). These 2 regions exhibit high interannual variability caused by the El Niño-Southern Oscillation (ENSO) cycle. During the warm phases of ENSO, i.e. El Niño events, upwelling is very much weaker, causing a major reduction in primary production (Barber \& Chávez 1983) and a dramatic impoverishment of the whole marine ecosystem (see review by Arntz \& Farhbach 1996).
In the northern upwelling region $\left(18^{\circ}-30^{\circ} \mathrm{S}\right)$, most biological production occurs close to the coast, associated with a very narrow continental shelf. However, this narrow band of water has an extremely high productive capacity which sustains a major fishery with catches of up to 5-6 million tonnes annually, about $40 \%$ of the total annual landings of the Chile-Peru upwelling ecosystem (Blanco et al. 2001). This region may also significantly contribute to climate regulation in the southern hemisphere because a substantial exchange of heat and $\mathrm{CO}_{2}$ can occur between the atmosphere and the cold, nutrientrich, $\mathrm{CO}_{2}$ saturated upwelling waters. This fertilization of the photic zone increases primary production and the uptake of $\mathrm{CO}_{2}$ from the atmosphere, promoting carbon export to depth.

The central/southern region $\left(30-42^{\circ} \mathrm{S}\right)$ includes several coastal upwelling centers (Fonseca \& Farías 1987) which exhibit strong seasonal variation. Upwelling intensifies during the spring-summer period (Cáceres \& Arcos 1991, Figueroa \& Moffat 2000) and downwelling occurs during the winter due to the prevalence of strong north winds. The continental shelf is considerably wider (up to ca. 40 $\mathrm{km}$ ) than in the north and, in places, is crossed by submarine canyons (Figueroa \& Moffat 2000). River runoff and rainfall are high in this area and low salinity waters can extend well offshore during the winter-early spring period in association with waters flowing northward from the fjord area (Strub et al. 1998). Some of the highest primary production rates in the coastal waters of Chile have been observed in this region (Daneri et al. 2000). This high productivity underlies one of the largest fisheries of jack mackerel Trachurus murphyi in the world. The $\mathrm{OMZ}$ in this area is deeper $(>100 \mathrm{~m})$ and less intense ( $>0.5 \mathrm{ml} \mathrm{L}^{-1}$ ) than further north. Where it overlies the shelf sediments, there is an extended period of suboxia in the benthic environment, which results in high biomasses of the sulfide-dependent giant bacterium Thioploca (Gallardo 1977).

The austral fjords region $\left(42^{\circ}-55^{\circ} \mathrm{S}\right)$ of Chile is the least studied zone. Here, the water in the inlets originates from SAW and the melting of resident glaciers. At these latitudes, the WWD reaches the coast and divides into the northward flowing Humboldt Current and the poleward Cape Horn Current, which passes around the continent through the Drake Passage, influencing both the east and west coasts of South America (Pickard 1973). 
Biogeographical Partitioning And The Biodiversity OF The CME

Much of the theory and practice regarding biogeographical partitioning and the biological diversity of ecosystems come from terrestrial communities and are usually based on geographical discontinuities. The dynamical and three-dimensional character of the ocean makes the identification of biogeographical regions in marine systems more complex. Thus, any physical boundaries to delineate biomes, provinces, or biogeographical units should, in most cases, be considered as transient and subject to seasonal and/or interannual variations.

According to Longhurst (1998), the south-eastern Pacific can be viewed as part of the Pacific coastal biome and may incorporate characteristics from three larger scale systems: the Trade Wind, Westerlies, and Polar biomes. These hypothetical domains are in agreement with the idea of there being three physical-chemical environments and biogeographical units in the CME (Fernández et al. 2000). The Pacific Trade Wind biome corresponds to the tropical ocean. On an annual basis, there is a net inward flux of heat across the sea surface and the upper mixed layer and tropical thermocline are maintained throughout the year. Its limits vary roughly from $5^{\circ} \mathrm{S}$ to around the tropical convergence $\left(30^{\circ} \mathrm{S}\right)$. The Westerlies biome is characterized by a highly seasonal mixed layer which deepens in winter due to increased wind stress. This biome can be considered as a transition zone between the Trade Wind and Polar biomes with a southern limit at about $55^{\circ} \mathrm{S}$, the latitude at which subduction of Antarctic Intermediate waters (AAIW) takes place.

Several studies of benthic and pelagic marine communities in the south-eastern Pacific also suggest the existence of three major biogeographic units that coincide, in general terms, with the biomes proposed by Longhurst (1998). However, the approaches used so far and necessary in the future, and the types of information currently available and those which will be required for the characterization of diversity patterns in these biogeographical regions differ. For this reason, the benthic and pelagic components have been treated separately in this review. However, the apparent correspondence of the boundaries of the three biogeographical regions for both components suggests that fu- ture studies should include a closer integration of the benthic and pelagic systems.

The three notional biogeographical regions of the CME (Fig.1) will now be discussed in more detail.

\section{The Pelagic System Of The Cme}

The northern upwelling region (NUR)

Coastal upwelling is the key process determining productivity in the NUR. Although pelagic organisms benefit from the high productivity of upwelling sites, they also have to cope with the variable conditions in this zone. Understanding the physical and biological interactions occurring in upwelling systems should provide insight into the processes that control the production and biological diversity of pelagic assemblages. Although much information on some of these interactions has already been gathered (Mann \& Hilborn 1992, Summerhayes et al. 1995), most of it comes from other upwelling areas, such as the Benguela System (Verheye et al. 1992, Roy 1998), the California Current system (Wing et al. 1998), and the Oregon system (Peterson et al. 1979, Wroblewski 1982). Details of the physical-biological interactions that take place in the coastal upwelling zones of the NUR are much more limited and restricted to some particular conditions and sites (e.g. Escribano \& Hidalgo 2000, Escribano et al. 2001, 2002, Giraldo et al. 2002). Recent studies (Marín et al. 2001) have provided data that may help in understanding the mechanisms which maintain the presence of pelagic populations in the food-rich coastal zone of the NUR. Off the Mejillones Peninsula ( $23^{\circ} \mathrm{S}$ ), the interaction between a poleward flow and cold upwelling plumes may give rise to large eddies that act as efficient retention mechanisms and prevent the offshore advection of zooplankton (Giraldo $e t$ al. 2002) and fish larvae (Rojas et al. 2002). A major finding is that, for most species, diel vertical migrations to maintain the populations in the foodrich upwelling centers do not seem to be necessary. Indeed, many species appear to be restricted to the upper layer $(<100 \mathrm{~m})$, possibly constrained by the shallow OMZ (Escribano \& Hidalgo 2000, Morales et al. 1996b). The pelagic ecosystem of the NUR is subject to weak seasonality, and also to strong interannual variation due to the ENSO cycle. 
The phytoplankton in the coastal zone is dominated by large diatoms and dinoflagellates, typical of upwelling systems. About 200 species from five taxonomic groups have been identified. In the nearshore zone $(<10 \mathrm{~nm})$, diatoms predominate whereas, offshore, dinoflagellates account for more than $80 \%$ of the total numerical abundance (Avaria $\&$ Muñoz 1983). The diatoms are mainly of the genera Leptocylindrus, Rhizosolenia, Detonula, Nitzschia, Chaetoceros, and Skeletonema and the dominant genera of dinoflagellates are Ceratium, Prorocentrum, and Gymnodinium (Avaria \& Muñoz 1983). The nanoplankton ( $<20 \mathrm{~mm})$, which consists of small diatoms, naked dinoflagellates, and autotrophic protozoa, has not received attention. Small phytoplankton, including nano and picoplankton, may account for a large proportion (> 60\%) of the primary production and chlorophyll a concentration in the coastal waters of the NUR (González et al. 1998, Iriarte et al. 2000). Also, large numbers of small Prochlorococcus and Synnecococcus have been reported within the OMZ, apparently photosynthesising under low oxygen conditions (Ulloa pers. comm.). Adaptations to these particular conditions may have given rise to a large amount of genetic variability which warrants the use of molecular approaches to identify the species present and investigate the degree of diversity. This lack of knowledge also applies to the microbial components in the NUR. Large amounts of bacterioplankton and protozoa can be anticipated, associated with the phytoplankton blooms following upwelling, but the study of the biodiversity of these components is not likely in the near future. The zooplankton in the NUR has received more attention. Although the dominant species can be considered to be part of the subantarctic fauna, they are mixed with species of tropical and equatorial origins. The most studied groups are copepods (Heinrich 1973, Vidal 1976, Hidalgo \& Escribano 2001) and euphausiids (Antezana 1978, Fernández et al. 2002). Fifty species of copepods have been recognized, the dominant ones being the herbivores Calanus chilensis, Centropages brachiatus, Paracalanus parvus, Acartia tonsa, and Eucalanus inermis. C. chilensis is endemic to the Humboldt Current (Marín et al. 1994), whereas C. brachiatus, P. parvus, and A. tonsa are cosmopolites and widely distributed along the Chilean coast. The genus Eucalanus may be represented by about six species which have not yet been clearly defined (Hidalgo \& Escribano unpublished data), though E. inermis is a typical tropical species. Small copepods are also abundant components of the epipelagic zooplankton among which the dominant genera are Oithona and Oncaea. Of the euphausiids, the endemic species of the Humboldt Current, Euphausia mucronata, is noteworthy in view of its high abundance, wide distribution, and close association with the OMZ (Antezana 1978). This species forms large aggregations in the upwelling centers off northern Chile, possibly interacting with the early stages of anchovy during the winter spawning season (Escribano et al. 2000). Euphausia eximia is another abundant species, which increases in number during El Niño events (Antezana 1978, González et al. 2000). Gelatinous zooplankton may exhibit large seasonal variations in abundance (González et al. 2000), but taxonomic studies of this group have not yet developed.

Other important components of the pelagic ecosystem of the NUR are mesopelagic fish. There are few studies dealing with this group, mostly represented by myctophidae (Sielfeld et al. 1995), but their early life stages are abundant in the ichthyoplankton in the upwelling center off the Mejillones Peninsula (Loeb \& Rojas 1988, Rojas et al. 2002), suggesting that myctophid fish may contribute substantially to the total biomass of the pelagic system in this province. No studies have been made of trophic interactions in this ecosystem.

The economically important fishery of northern Chile is mostly sustained by the anchovy Engraulis ringens and the sardine Sardinops sagax. The early stages of these small pelagic fish are known to feed on microplankton, composed of a mixture of diatoms, flagellates, copepod eggs, and nauplii, whereas later stages might well prey upon the abundant copepod populations in the coastal upwelling zone. Euphausiids and gelatinous zooplankton may, on the other hand, feed on anchovy eggs. The early mortality of small pelagic fish due to size-dependent predation can, therefore, be anticipated. These potential trophic interactions require urgent study to evaluate their roles in structuring pelagic assemblages in the NUR.

The ENSO cycle can cause abrupt changes in the planktonic community of the NUR. During the warm phase, small diatoms and flagellates replace the large forms that predominate during cold 
upwelling conditions, and account for most of the primary production (Iriarte et al. 2000). Species replacements also occur in the zooplankton (Hidalgo \& Escribano 2001): The community of copepods (mainly Calanus and Eucalanus) and euphausiids present during upwelling conditions is succeeded by the cyclopoid copepods, Paracalanus and Acartia, during El Niño events (González et al. 2002). A reduction in the size of mature copepods also appears to be associated with El Niño (Ulloa et al. 2001). All of these changes in the structure of the pelagic system may have profound implications for the functioning and productivity of the NUR and need also to be considered in future ecosystem studies.

\section{THE CENTRAL/SOUTHERN UPWELLING REGION (CSUR)}

Studies of physical-biological interactions in the pelagic realm of the CSUR are scarce. Peterson \& Bellantoni (1987) examined the influence of water column stratification, phytoplankton size, and copepod fecundity off Concepción ( $36^{\circ} \mathrm{S}$ ), and Peterson et al. (1988) investigated the coupling between primary and secondary production in this productive upwelling center. Additional studies have dealt with the vertical distribution and spatial variation of dominant copepods (Castro et al. 1991, 1993). More recently, the influence of physicalbiological interactions on the early life stages of clupeids in the upwelling zone off Concepción has been described (Castro \& Hernández 2000, Castro et al. 2000). These studies suggest that mixing and advection can have a strong influence on the population dynamics of dominant zooplankton and small pelagic fish. Thus, physical processes may be more important in regulating pelagic populations in the CSUR than in the NUR, where biological interactions seem to play a greater role.

The plankton assemblages in the pelagic systems of the CSUR and the NUR differ slightly, in terms of a few species, but the 2 regions have many phytoplankton and zooplankton in common. In the CSUR, the phytoplankton is dominated by large diatoms for most of the year (Avaria \& Muñoz 1982). The species of zooplankton present in both the CSUR and the NUR include, among the dominant herbivores, the endemic species $C$. chilensis and E. mucronata, which are distributed down to mid latitudes $\left(45^{\circ} \mathrm{S}\right)$. The CSUR fauna are mostly of subantarctic origin, however, tropical or subtropical species being scarce or absent. Nearly 35 species of copepods have been cited for the CSUR (Björnberg 1973). The most abundant species of large copepods are Rhyncalanus nasutus and Calanoides patagoniensis (Arcos 1975, Castro et al. 1991) and, of euphausiids, Thysanoessa gregaria and Euphausia lucens, which become even more numerous further south in the fjords region. About 45 species from the groups hydrozoa, siphonophore, ctenophore, chaetognath, and appendicularia have been identified off Valparaíso (Palma 1973, Palma \& Rosales 1995).

Species such as the Galatheidae crustaceans are important fishery resources in the CSUR. Of about 16 species identified in Chilean waters (Retamal 1981), only 2, Pleuroncodes monodon and Cervimunida johni, have been exploited. Although these species are distributed from Peru to southern Chile, the fishing area has been restricted to between $30^{\circ}$ and $37^{\circ}$ $\mathrm{S}$ (Palma 1994). The anchovy E. ringens is present between $32^{\circ}$ and $40^{\circ} \mathrm{S}$, but this population appears to be distinct and geographically separated from that in the NUR because no anchovy fishing has been reported in the transition zone $\left(26^{\circ}-32^{\circ} \mathrm{S}\right)$ between the two regions. The degree of interbreeding is unclear and to discover whether these populations differ from each other may require the use of molecular techniques. The jack mackerel, Trachurus murphyi, is a major fishery resource in the upwelling zone between Valparaíso $\left(33^{\circ} \mathrm{S}\right)$ and the Gulf of Arauco $\left(38^{\circ} \mathrm{S}\right)$. This species, however, undergoes large-scale migrations and is widely distributed in the Pacific Ocean, so that it has been difficult to identify and allocate populations to specific geographical locations. The identification of individual populations in order to answer questions about the population dynamics and ecology of this species is an important and unsolved issue for managing this resource. Studies of the feeding behaviour of jack mackerel suggest that this species consumes a wide range of food types, though euphausiids are a major component of its diet (Medina \& Arancibia 2002). Other preys are mycthopids, anchovies, copepods, and chaetognath (Medina \& Arancibia 2002). The Chilean hake Merluccius gayi is also an important resource in the CSUR. This species inhabits mid-depths $(200-400 \mathrm{~m})$ and also feeds mostly on euphausiids (Meléndez 1983, Arancibia 1989).

From these studies, it is apparent that euphausiids, 
which form dense aggregations in the coastal waters of the CSUR (Antezana 1970), are a key trophic link in the food chain between phytoplankton and fish production, sustaining large biomasses of jack mackerel and the Chilean hake. There have been no ecological studies of euphausiids in the CSUR and this is an issue that needs urgent attention.

The AustRAL FJORDS REGION (AFR)

The composition of the fauna and flora in the AFR is greatly influenced by the Antarctic continent though it also includes species from the Atlantic coast, because both zones are influenced by the Cape Horn Current. The phytoplankton community of the AFR is characterized by up to 135 species of diatoms and dinoflagellates (Uribe 1992). The dominant genera of diatoms are Chaetoceros, Skeletonema, Nitzschia, and Thalassiosira, with several species yet to be identified (Avaria 1970, Uribe 1992). Dinoflagellate genera include toxic species of Alexandrium, Dinophysis, Gonyaulax, and Amphidom. Red tides are common in the area (see Clement \& Guzmán 1989 for a review).

The zooplankton assemblages are largely dominated by dense aggregations of euphausiids, commonly composed of E. lucens, E. vallentini, and Thysanoessa gregaria (Antezana 1976). In the estuarine conditions nearshore in the inlets, the zooplankton communities contain a rich variety of cladocera and meroplanktonic larvae of crustacean decapoda mixed with an abundant, diverse community of epipelagic copepods (Marín \& Antezana 1985). Dominant copepods include the calanoids Calanus australis, Calanoides patagoniensis, and Drepanopus forcepatus.

Over the continental shelf of the AFR, the fish community is dominated by the demersal species $M a$ cruronus magellanicus and Merluccius australis. Both are comercially exploited and their apparently high biomasses might be sustained by the abundance of euphausiids available, but trophic interactions in this region are unknown and deserve future attention.

THE BENTHIC SYSTEM OF THE CME

An increasing number of reports of large scale patterns of diversity in the marine benthos of Chile, also identifying possible causal factors affecting biodiversity, have appeared in recent years. This may be a response to the alarming decreases in biodiversity reported for ecosystems elsewhere and also to the intense exploitation of the economically valuable benthic resources in Chile. The studies are important since they allow the determination of (1) biogeographical units, (2) areas of high species diversity, (3) areas with a high frequency of endemic species, as well as (4) gaps in existing knowledge. The information available is still scarce and unbalanced for the different taxa, geographical areas, and depths. Moreover, the scale of analysis needs to be considered before final conclusions can be drawn since the scope of the databases might have influenced the patterns of diversity reported so far (Rivadeneira et al. 2002).

Large scale diversity patterns of benthic macroinvertebrates and macroalgae have recently been summarized by Fernández et al. (2000); data for the best studied species obtained during surveys conducted from the early nineteenth century to the present were used to compile databases which aided the analyses of diversity. The number of species included in studies of latitudinal diversity patterns of benthic invertebrates has increased from the first work conducted by Viviani (1979) to present not only due to the inclusion of more taxa but also to more comprehensive databases. The most recent compilation (Lancellotti \& Vásquez 2000) is based on 1597 species of Porifera, Anthozoa, Polychaeta, Mollusca (Polyplacophora, Gastropoda, Bivalvia), Crustacea (Cirripedia, Amphipoda, Isopoda, Brachyura, Anomura), Echinodermata (Asteriodea, Ophiuroidea, Echinoidea, Holothuroidea), and Ascidiacea present between $18^{\circ}$ and $55^{\circ} \mathrm{S}$. In the same study area, 508 species of macroalgae have also been reported (Santelices 1980). Analysis of this information has been used to delineate biogeographical provinces (Castilla 1979, Viviani 1979, Santelices 1980, Brattström \& Johanssen 1983, Santelices \& Marquet 1998, Lancellotti \& Vásquez 1999, Valdovinos et al. 2003). Although the taxa and depths considered in these studies varied and different patterns were proposed, there were some general coincidences. Firstly, two major biogeographical provinces (see Lancellotti \& Vásquez 1999) were identified: the Perú-Chile province (from Paita in Perú to Valparaíso in Chile) and the Magellanic province (Chiloé Island to Cape Horn) (Fig. 2). The latitudinal limits of each 
province differed by up to $2^{\circ}-3^{\circ}$ between the various authors, the biogeographical boundary at $42^{\circ} \mathrm{S}$ being better defined for shallow than for deep water species (Brattström \& Johanssen 1983). Secondly, most authors recognized a diffuse 'transition zone' in central Chile, from around Valparaíso down to Chiloé Island. However, the breaks in species distribution varied both between the taxa of the benthic invertebrates (Viviani 1979, Brattström \& Johanssen 1983, Lancellotti \& Vásquez 1999) and between the benthic invertebrates and the macroalgae (Santelices \& Marquet 1998). An area of macroalgal species affinity, from the Strait of Magellan to Cape Horn $\left(54^{\circ}-55^{\circ} \mathrm{S}\right)$, was identified with mostly subantarctic, endemic species, many with restricted distribution. A second, more extensive area between $5^{\circ}$ and $53^{\circ}$ $\mathrm{S}$ is populated by many endemic and several bipolar species, and there is a gradual northward decrease in the number of antarctic species present. Within this region, a small discontinuity, probably related to upwelling events, is observed at $30^{\circ} \mathrm{S}$ (Santelices 1980). Recent studies, conducted on large (Lancelloti \& Vásquez 2000) and small spatial scales, have shown that, between $30^{\circ}$ and $32^{\circ} \mathrm{S}$, a break may exist in the distribution of species of benthic invertebrates. However, this boundary does not seem to be as well defined as that identified in the WWD (see below).

An outstanding feature of this region is the latitudinal pattern of species richness of several taxa of marine invertebrates (Viviani 1979, Brattström \& Johanssen 1983, Lancellotti \& Vásquez 2000, Valdovinos et al. 2003). In the northern hemisphere, species diversity is maximal near the equator and declines northwards, both in terrestrial taxa and in marine invertebrates and fish (Rohde et al. 1993; Roy et al. 1994, 1998, 2000). Along the coast of Chile, however, species richness of several benthic taxa decreases as expected with increasing latitude between 18 and 40-45 S, and then increases dramatically further south. Several authors have hypothesized that this inverse pattern of diversity might be explained by the presence of the antarctic fauna (Gallardo 1987, Clarke \& Crame 1997). An alternative explanation is that this inverse pattern of diversity is related to the larger area of habitable continental shelf south of $40^{\circ} \mathrm{S}$ (Valdovinos et al. 2003). What is clear is that the latitudinal gradients in solar radiation, water temperature and, thus, productivity do not explain the anomalous diversity of benthic invertebrates in the southeastern Pacific (Rohde et al. 1993; Roy et al. 1994, 1998, 2000, Macpherson 2002). This anomaly is not general in the southern hemisphere, however. Some taxa of marine benthic invertebrates do follow the "normal" latitudinal diversity gradient (e.g., Brachyura and Anomura; Boschi (2000) and Astorga et al. (submitted) showed that their distribution patterns are linked to the sea surface temperature in the southern ocean. These authors hypothesized that this was related to the modes of larval development. This work was based on databases compiled by Retamal (1981) and Boschi 2000. The debate about what determines patterns of diversity of marine organisms is just starting, and, to progress with this, more information is going to be needed. Databases for other groups of benthic marine invertebrates are also required as well as information on their modes of larval development. Most of the patterns described above are for macrofauna; information about the microfauna of marine invertebrates is limited and urgently needed. Once this is available, comparative analyses with other oceans can be conducted, and this could greatly help in understanding the factors which influence marine biodiversity. It is interesting to note that the patterns of diversity of macroalgae (Santelices 1980) and fish (Rohde et al. 1993, Ojeda et al. 2000, Macpherson 2002) are similar in the two hemispheres and that, within each group, similar patterns of development have been reported. This strongly suggests that understanding the life histories and development of benthic invertebrate species is particularly important. Other evidence supporting the link between diversity and modes of development of benthic invertebrates has been provided by the analysis of size ranges (Santelices \& Marquet 1998, Valdovinos et al. 2003, Astorga et al. submitted). These seem to decrease south of $40-45^{\circ} \mathrm{S}$ in most species of benthic invertebrates and macroalgae, but not in the groups with similar motile phases which occur between $18^{\circ}$ and $55^{\circ} \mathrm{S}$ (e.g. Brachyura, Anomura, fish). Due to the small size ranges of the species south of $40-45^{\circ} \mathrm{S}$, a high frequency of endemic benthic invertebrates is observed around the southern tip of South America.

Although analyses of large scale patterns of diversity based on databases compiled using the existing literature are of major interest, more site specific information is needed for a better definition of diversity, for the identification of causal factors, 
and for conservation plans. This type of information is lacking for most coastal habitats. Even though the benthic marine communities of Chile have gained recognition as some of the best known in the world, and examples of Chilean studies are starting to appear in basic ecological textbooks (e.g., Giller 1984, Putman 1994, Paine 1994, Raffaelli \& Hawkins 1996, Barnes \& Hughes 1999), the data come from a relatively small number of study sites (central Chile and around Mehuín) and are mostly restricted to the intertidal zone (particularly rocky shores). Information on intertidal communities for the rest of the coast of Chile is still scarce; the diversity and structure of the heavily exploited benthic communities in the shallow subtidal fringe (0-30 m depth) are very little understood. In Chile, nearshore invertebrates and algae are economically and socially important, since more than 30,000 fishermen are involved in harvesting them (Bustamante \& Castilla 1987). These benthic systems require the most immediate attention because (1) their diversity is higher, (2) they support important economic activities, and (3) they are heavily impacted by different types of human activity. Recent extensive surveys of benthic invertebrates in deeper areas by the German research vessel, De Sonne, are also of interest in this context. It is also important to emphasize that large scale analyses of biodiversity based on extensive sitespecific samples may yield results which are different from those derived from databases. A recent study showed that distribution patterns of species richness and turnover along the coast of Chile, between $18^{\circ}$ and $42^{\circ} \mathrm{S}$, varied according to the spatial scale used; databases for intertidal invertebrates, for example, showed, around $30-32^{\circ} \mathrm{S}$, a mid-latitudinal peak of species richness, (Rivadeneira et al. 2002). However, extensive field studies in the intertidal zone revealed that changes in abundance, recruitment and reproductive patterns do, in fact, occur at that latitude (Camus 1998, Brazeiro 1999, Broitman et al. 2001, Rivadeneira et al. 2002, Fernández unpublished data). None of these latter patterns became evident using databases. The documentation of meso-scale patterns (intermediate between the small, local-scale of field observations and the continental scales of traditional biogeographical analyses) are virtually non-existent in Chile though efforts in this direction have been made, in the last 10 years, for intertidal rocky shores and sandy beaches (Camus 1998, Brazeiro 1999, Broitman et al. 2001, Rivadeneira et al. 2002, Jaramillo unpublished data). More studies expanding the traditional small scale of analysis used by benthic ecologists are needed in Chile to draw final conclusions.

\section{CONCLUDING REMARKS}

This paper provides a brief account of what is currently known about the structure and functioning of the CME. Certainly, many aspects and much information have not been covered in this survey. However, at this point, it seems more relevant to identify and emphasize the issues that require urgent attention in the context of the conservation of biological diversity in the CME. The types of biological and ecological data required to further advance biodiversity studies in Chile have already been identified by Fernández et al. 2000. Future work should include (1) extensive surveys to collect data on coastal communities which are subjected to human impacts and in little studied geographical locations, (2) surveys and analyses of existing samples to increase the information on large-scale patterns of species distribution for some taxonomic groups, (3) efforts to coordinate ongoing initiatives directed towards biodiversity studies (e.g., those of CONA and CASEB, and individual efforts conducted by taxonomists), (4) the compilation and organization of existing biological and ecological information, (5) the assessment of the conservation statuses of species, (6) the evaluation of natural factors which influence diversity, (7) the assessment of the effect of species introduced by the aquaculture industry on local biodiversity and ecosystem functioning, and (8) the evaluation of the effect of human activities (e.g., pollution, exploitation of key predators of benthic communities) on local biodiversity, among others.

The Chilean National Commission for Science and Technology (CONICYT) recently funded the Center for Advanced Studies in Ecology and Biodiversity (CASEB). This is the first national initiative of this type, and the first signal indicating recognition of the need to study biodiversity, both marine and terrestrial, in Chile. Several CASEB research programs involve different aspects of biodiversity in the nearshore ecosystems (0-40 m depth) and the re- 
sults of these studies are being used by the National Environmental Commission (CONAMA) to design conservation plans for Chile. The diversity of the nearshore is being examined from large to small spatial scales using several different approaches (e.g. data compilation, molecular techniques, and field and experimental studies). Current work on large scale patterns of diversity and the processes producing them (Santelices \& Marquet 1998, Wieters 2000, Valdovinos et al. 2003, Astorga et al. submitted) mostly involves the compilation of databases of marine species (e.g., polychaetes, molluscs, crustaceans, algae, bryozoans, sponges, etc). These will later be integrated into a GIS-based grid system to map the distribution of these organisms with the aim of designing a network of marine protected areas (Botsford et al. 2001). The information will also enable the identification of areas of high species diversity, and those which possess unique characteristics in terms of ecosystem processes (e.g. disturbance, upwelling regimes) and taxa (e.g. endemic and key species). The development of a biogeographical database for Chilean marine flora and fauna was initiated between 1997 and 2000 and has become a major component of the work of CASEB. Although several of the needs listed earlier are being addressed by CASEB programs, extensive surveys along the coast of Chile were not funded, and, in spite of its urgency, it is unlikely that this type of project will receive national funding in the near future. What is, therefore, now required is the coordination of national institutions and researchers, and their linking to international networking. The importance of international cooperation for studies of biodiversity in Chile is clearly shown by (1) the results presented at the first International Marine Macroecology Workshop (see summary in Trends in Ecology and Evolution, February 2001, 67-69), and (2) the outcome of ongoing international programs. The latter have allowed and are allowing the comparison of species diversity databases from Chile and other countries as well as coordinating efforts to increase meso-scale field studies in the upwelling regions of the northeastern and southeastern Pacific (e.g. PISCO Project-CASEB, Mellon Foundation-CASEB). More work on solving taxonomic problems is required, and the use of modern molecular techniques may help where traditional methods have not yet been successful (e.g. Castilla et al. 2002). Although it is unlikely that molecular methods will be generally available in the near future, there are programs at the CASEB Laboratory of Molecular Diversity and international efforts in which Chilean scientists should become involved. The ultimate goal of such initiatives would be the construction of global genetic data banks for targeted taxonomic groups.

With regards to ecosystem functioning and biological diversity, the large scale and long term studies providing insights to the key processes that help to maintain biodiversity are still at an early stage in Chile. However, national initiatives such as the FONDAP (Funding for Advanced Science in Priority Areas) programs established by CONICYT will help in accumulating further knowledge about the CME. Two of these programs are the already mentioned CASEB and COPAS, the FONDAP Center for Oceanographic research in the Eastern South Pacific (COPAS), based at University of Concepción, is studying interannual variability caused by the ENSO cycle and how the whole of the CME responds to interannual variations from cold to warm regimes, both relevant questions in the context of ecosystem structure and functioning. To tackle these problems, time-series studies based on current moorings off Iquique $\left(20^{\circ} \mathrm{S}\right)$ and Coquimbo $\left(30^{\circ} \mathrm{S}\right)$ are in progress. COPAS is also funding an integrated physical-biological time series station off Antofagasta $\left(23^{\circ} \mathrm{S}\right)$ and another monitoring physical, chemical, and biological variables off Concepción ( $36^{\circ} \mathrm{S}$ ). COPAS will also carry out further studies of the $\mathrm{OMZ}$ and coastal upwelling to improve our understanding of the functioning and structure of the CME. Latitudinal variability in upwelling might greatly explain many of the patterns of diversity observed in the CME. The potential biotopes provided by the distinctive vertical habitats must also be considered. The permanent pycnocline in the NUR, the seasonal pycnoclines in the CSUR and the AFR, and the $\mathrm{OMZ}$ are physical boundaries that promote the vertical partitioning of species assemblages into at least three distinguishable habitats: (1) the epipelagic euphotic zone, (2) the OMZ, and (3) the AAIW. Each may contain distinct ecosystems with their own energy pathways and biological communities. Of them, the AAIW, is the least studied and COPAS will rectify this in collaboration with international partners by conducting research cruises in the southern region of Chile during the next few years. 
It has been suggested that there may be a gradient in the potential for the dispersal of certain taxa along the coast of Chile (Gallardo \& Penchaszadeh 2001). Studies of meso- and smallscale patterns of diversity and the processes which determine them include (1) patterns of recruitment and the structure of intertidal and shallow subtidal benthic communities along biogeographical transition zones, (2) the influence of natural factors (e.g. the presence of adapted species, upwelling regimes, ENSO variability) on coastal communities, (3) the effects of different types of human impact (e.g. pollution, exploitation, introduction of exotic species) on benthic communities, and (4) genetic diversity in commercially important species (e.g. macroalgae, abalone, mackerel, anchovy). Some of the studies of human perturbations are conducted in the Marine Protected Area of Las Cruces where a 20-year database of coastal organism diversity is available.

\section{ACKNOWLEDGMENTS}

This paper is a joint contribution from COPAS (Centro de Investigación Oceanográfica en el Pacífico Sur-Oriental (COPAS) and CASEB (Centro de Ecología y Biodiversidad), both funded by the FONDAP Program of CONICYT- Chile. We appreciate the collaboration of A. Astorga, P. Barría and S. Mora in preparing the data base for pelagic fish. We also acknowledge contributions from Victor A. Gallardo, Fabián Jaksic, Pablo Marquet and Eduardo Tarifeño.

\section{REFERENCES}

Antezana, T. 1970. Eufáusidos de la costa de Chile. Su rol en la economía del mar. Revista de Biología Marina de Valparaíso 14: 19-27.

Antezana, T. 1976. Diversidad y equilibrio ecológico en comunidades pelágicas. In: F. Orrego V. (Ed.), Preservación del medio ambiente marino. Instituto de Estudios Internacionales, Universidad de Chile. Edit. Universidad Técnica de Chile, pp. 40-54.

Antezana, T. 1978. Distribution of euphausiids in the Chile-Perú Current with particular reference to the endemic Euphausia mucronata and the oxygen minima layer. Ph.D. thesis, University of California, USA, unpublished.

Antezana, T. \& N. Bahamonde. 2002. History of marine science in Chile. In: K.R. Benson \& P.F.
Rehbock (Eds.), Oceanographic History: The Pacific and Beyond, University of Washington Press. Seattle, pp. 155-166.

Arancibia, H. 1989. Distribution patterns, trophic relationships and stock interactions in the demersal fish assemblage off central Chile. Dr. rer. Nat. Thesis. University of Bremen, German, $221 \mathrm{pp}$.

Arcos, D.F. 1975. Copépodos calanoídeos de la Bahía de Concepción, Chile. Conocimiento sistemático y variación estacional. Gayana Zoología 32: 43.

ArntZ, W.E. \& E. Fahrbach. 1996. El Niño, experimento climático de la naturaleza. Fondo de Cultura Económica, Mexico, DF, 312 pp.

Astorga, A., M. Fernández \& E.E. Boschi. submitted. Two oceans, two taxa and one mode of development: latitudinal diversity patterns of South American crabs and test for causal processes. Ecology Letters.

Avaria, S. 1970. Fitoplancton de la expedición Donna Berta en la zona de Puerto Montt-Aysén. Revista de Biología Marina de Valparaíso 14: 1-17.

Avaria, S. \& P. Muñoz. 1982. Producción actual, biomasas y composición específica del fitoplancton de la bahía de Valparaíso en 1979. Revista de Biología Marina de Valparaíso 18: 129-157.

Avaria, S. \& P. MuÑoz. 1983. Composición y biomasa del fitoplancton marino del norte de Chile en mayo de 1981 (operación oceanográfica MarChile XII-ERFEN III). Ciencia y Tecnología del Mar, CONA 7: 109-140.

Blanco, J.L., A.C. Thomas, M.E. Carr \& PT Strub. 2001. Seasonal climatology of hydrographic conditions in the upwelling region off northern Chile. Journal of Geophysical Research 106: 11451-11467.

BArber, R.T. \& E.P. ChÁvez. 1983. Biological consequences of El Niño. Science 22: 1203-1210.

BARBER, R.T. \& R.L. SMith. 1981. Coastal upwelling ecosystems. In: A.R. Longhurst (Ed.). Analysis of Marine Ecosystems. Academic Press, pp. 31-68.

Barnes, R.S.K. \& R.N. Hughes. 1999 An introduction to marine ecology. Third edition. Blackwell Science, London. 286 pp.

Bellorín, A. \& E.C. Oliveira. 2001. Introducción de especies exóticas de algas marinas: situación en América Latina. In: Alveal, K. \& T. Antezana (Eds), Sustentabilidad de la Biodiversidad. Universidad de Concepción, Chile pp. 693-701.

BJörnberG, T. 1973. The planktonic copepods of the MARCHILE I Expedition and of the "Eltanin" cruises 3-6 taken in the SE Pacific. Boletín Zoología y Biología Marina N.S. 30: 245-394.

BoschI, E.E. 2000. Species of decapod crustaceans and their distribution in the marine zoogeographic provinces. Revista de Investigación y Desarrollo Pesquero 13: 7-136.

Botsford, L., A. Hasting \& S. Gaines. 2001. Depen- 
dence of sustainability on the configuration of marine reserves and larval dispersal distances. Ecology Letters 4: 144-150.

BRATtSTRÖM, H. \& A. JohAnsSEn. 1983. Ecological and regional zoogeography of the marine benthic fauna of Chile. Sarsia 68: 289-339.

Brazeiro, A. 1999. Community patterns in sandy beaches of Chile: richness, composition, distribution and abundance of species. Revista Chilena de Historia Natural 72: 93-105.

Broitman, B., S. NaVArRete, F. Smith \& S. Gaines. 2001. Geographic variation of Southeastern Pacific intertidal communities. Marine Ecology Progress Series 224: 21-34.

Bustamante, R.H. \& J.C. Castilla. 1987. The shellfishery in Chile: an analysis of 26 years of landings (1960-1985). Biología Pesquera 16: 79 97.

CÁceres, M. \& D.F. Arcos. 1991. Variabilidad en la estructura espacio-temporal de un área de surgencia frente a la costa de Concepción, Chile. Investigación Pesquera (Chile) 36: 27-38.

Camus, P.A. 1998. Estructura espacial de la diversidad en ensambles sésiles del intermareal rocoso de Chile centro-norte: la diversidad local como resultado de determinantes de multiescala. Ph.D. thesis dissertation, P. Universidad Católica de Chile, 262 pp.

Castilla, J.C. 1979. Características bióticas del Pacífico Sur-Oriental, con especial referencia al sector chileno. Revista Comisión Permanente Pacífico Sur 10: 167-182.

Castilla, J.C., A. G. Collins, C.P. Myer, R. Guíñez \& D.R. LinberG. 2002. Recent introduction of the dominant tunicate, Pyura praeputialies to Antofagasta, Chile. Molecular Ecology 11: 1579-1584

Castro, L.R. \& E.H. Hernández. 2000. Early life survival of the anchoveta Engraulis ringens off central Chile during the 1995 and 1996 Winter spawning seasons. Translation American Fishery Society. 129: 1107-1117.

Castro, L.R., G.R. Salinas \& E.H. Hernández. 2000. Environmental influences on winter spawning of the anchoveta Engraulis ringens off Central Chile. Marine Ecology Progress Series 197: 247258.

Castro, L.R., P.A. Bernal \& H.E. GonzÁlez. 1991. Vertical distribution of Copepods and the utilization of the chlorophyll-a rich layer within Concepción Bay, Chile. Estuarine Coastal and Shelf Sciences. 32: 243-256.

Castro, L.R., P.A. Bernal \& V.A. Troncoso. 1993. Coastal intrusion of copepods: mechanisms and consequences on the population biology of Rhincalanus nasutus. Journal of Plankton Research. 15: 501-515.

Carlton, J.T. \& J.B. Geller. 1993. Ecological roulette: The global transport of nonindigenous marine organisms. Science 261: 78-82.
Clarke, A. \& J.A. Crame. 1997. Diversity, latitude and time: patterns in the shallow sea. In: Marine Biodiversity, Cambridge University Press, pp. 122-145.

Clement, A. \& L. Guzmán. 1989. Red tides in the Chilean fjords. In: Okaichi, D.M, Anderson \& Namoto (Eds.), Red Tides: Biology, Environmental Science, and Toxicology: 121-124.

Cushing, D. H. 1982. Climate and fisheries. Academic Press, San Diego, USA. 372.

Daneri, G., V. Dellarossa, R. Quiñones, B. Jacob, P. Montero \& O. Ulloa. 2000. Primary production and community respiration in the Humboldt Current System off Chile and associated oceanic areas. Marine Ecology Progress Series 197: 4149.

Escribano, R. \& P. Hidalgo. 2000. Spatial distribution of copepods in the north of the Humboldt Current region off Chile during coastal upwelling. Journal of the Marine Biological Association U.K. 80: 283-290.

Escribano, R., V. Marín \& C. Irribarren. 2000. Distribution of Euphausia mucronata at the upwelling area of Peninsula Mejillones: the influence of the oxygen minimum layer. Scientia Marina. 64: 69-77.

Escribano, R., V. Marín \& P. Hidalgo. 2001. The influence of coastal upwelling on the distribution of Calanus chilensis in the Mejillones Peninsula (northern Chile): implications for its population dynamics. Hydrobiologia 453: 143-151.

Escribano, R., V. Marín, P. Hidalgo \& G. Olivares. 2002. Physical-biological interactions in the nearshore zone of the northern Humboldt Current ecosystem. In: J.C. Castilla \& J.L. Largier (Eds.), The Oceanography and Ecology of the Nearshore and Bays in Chile. Ediciones Universidad Católica de Chile, Santiago, Chile. pp. 145-175.

Fernández, M., E. Jaramillo, P.A. Marquet, C.A. Moreno, S.A. Navarrete, F.P. OJeda, C.R. VAldovinos \& J.A. VÁsQuez. 2000. Diversity, dynamics and biogeography of Chilean benthic nearshore ecosystems: an overview and guidelines for conservation. Revista Chilena de Historia Natural 73: 797-830.

Fernández, D., R. Escribano \& P. Hidalgo. 2002. Distribución de eufáusidos en el sistema de surgencia frente a la península de Mejillones $\left(23^{\circ}\right.$ S) asociada a condiciones previas y durante El Niño 1997-98. Investigaciones Marinas 31: 56-68.

Figueroa, D. \& C. Moffat. 2000. On the influence of topography in the induction of coastal upwelling along the Chilean coast. Geophysical Research Letters 27: 3905-3908.

Fonseca, T.R. \& M. Farías. 1987. Estudio del proceso de surgencia en la costa chilena utilizando percepción remota. Investigaciones Pesqueras 34: 33-46.

Gallardo, C.S. \& P.E. Penchaszadeh. 2001. Hatching 
mode and latitude in marine gastropods: revisiting Thorson's paradigm in the southern hemisphere. Marine Biology 138: 547-552.

Gallardo, V.A. 1977. Large benthic microbial communities in sulfide biota under Perú-Chile subsurface countercurrent. Nature 268: 331-332.

Gallardo, V.A. 1987. The sublittoral macrofaunal benthos of the Antarctic shelf. Environmental International 13: 71-81.

Giraldo, A., R. Escribano \& V. Marín. 2002. Spatial distribution of Calanus chilensis off Mejillones Peninsula (northern Chile): ecological consequences upon coastal upwelling. Marine Ecology Progress Series 230: 225-234.

GLOBEC. 1999. Global Ocean Ecosystem Dynamics. Implementation Plan. IGBP Report 47.

Glowka, L. 1994. A Guide to the Convention on Biological Diversity, IUCN Gland and Cambridge. $161 \mathrm{pp}$.

GonzÁlez, H.E., V. C. Ortiz \& M. Sobarzo. 2000. The role of faecal material in the particulate organic carbon flux, in the northern Humboldt Current, Chile $\left(23^{\circ} \mathrm{S}\right)$, before and during the 1997-1998 El Niño. Journal of Plankton Research. 22: 499529.

González, H.E., G. Daneri, D. Figueroa, J. L. Iriarte, N. Lefevre, G. Pizarro, R. Quiñones, M. Sobarzo \& A. TRONCOSO. 1998. Producción primaria y su destino en la trama trófica pelágica y océano profundo e intercambio océano-atmósfera de $\mathrm{CO}_{2}$ en la zona norte de la Corriente de Humboldt $\left(23^{\circ}\right.$ S): Posibles efectos del evento El Niño, 1997-98 en Chile. Revista Chilena de Historia Natural 71: 429-458.

González, H.E., F. Pagés, M. Sobarzo \& R. Escribano. 2002. Effects of the 1997/98 El Niño on the oceanographic conditions and zooplankton community structure in the coastal upwelling system off northern Chile. Investigaciones Marinas Valparaíso (extended abstract) 30: 112-114.

GILLER, P.S. 1984. Community structure and the niche. Chapman \& Hall. Outline Studies in Ecology: 175.

HeINRICH, A.K. 1973. Horizontal distribution of copepods, in the Perú Current region. Oceanology 13: 97-103.

HidAlGo, P. \& R. EsCRIBANO. 2001. Succession of pelagiccopepod species during the period 1996/1998 in northern Chile: the influence of the 1997-98 El Niño. Hydrobiologia 453: 153-160.

Iriarte, J.L., G. Pizarro, V.A. Troncoso \& M. Sobarzo. 2000. Primary production and biomass sizefractioned phytoplankton off Antofagasta, Chile (23-24 ${ }^{\circ}$ S) during pre-El Niño and El Niño 1997. Journal of Marine Systems. 26:37-51.

Kennedy, T.A., S. Naeem, K.M. Howe, J.M.H. Knops, D. Tilman \& P. ReIch. 2002. Biodiversity as a barrier to ecological invasion. Nature 417: 636-638.
Lancellotti, D. \& J.A. VÁsQuez. 1999. Biogeographical patterns of benthic invertebrates in the southeastern Pacific littoral. Journal of Biogeography 26: 1001-1006.

Lancellotti, D. A. \& J.A. VÁsQuez. 2000. Zoogeografía de macroinvertebrados bentónicos de la costa de chile: contribución para la conservación marina. Revista Chilena de Historia Natural 73: 99-129.

LoEb, V. \& O. RoJAs. 1988. Interanual variation of ichthyoplankton composition and abundance relations off northern Chile, 1964-83. Fishery Bulletin 86:1-24.

LonghuRst, A. 1998. Ecological Geography of the Sea: 398. Academic Press, London.

Macpherson, E. 2002. Large-scale species-richness gradients in the Atlantic ocean. Proceedings of the Royal Society of London, Series Biological Sciences 269:1715-1720.

MANN, K.H. \& J.R.N. LAZIER. 1991. Dynamics of marine ecosystems: 563. Oxford, Blackwell Scientific Publications.

Mann, K.H. \& R. Hilborn. 1992. Benguela Trophic Functioning. South African Journal of Marine Sciences. 12: 561-585.

Marín, V. \& T. AnteZana. 1985. Species composition and relative abundance of copepods in Chilean fjords. Journal of Plankton Research. 7: 961-966.

Marín, V.H., S. Espinoza \& A. Fleminger. 1994. Morphometric study of Calanus chilensis males along the Chilean coast. Hydrobiologia 292/293: 75-80.

Marín, V.H., R. Escribano, L.E. Delgado, G. Olivares \& P. Hidalgo. 2001. Nearshore circulation in a coastal upwelling site off the northern Humboldt Current System. Continental Shelf Research 21: 1317-1329.

Medina, M. \& H. Arancibia. 2002. Dinámica trófica del jurel (Trachurus symmetricus murphyi) en el norte de Chile. Investigaciones Marinas 30: 45-56.

MelÉndez, R. 1983. Alimentación de Merlucius gayi (Guichenot) frente a Chile Central ( $\left.36^{\circ} 05-36^{\circ} 50\right)$. Boletín Museo Nacional de Historia Natural de Chile. 40: 145-152.

Morales, C.E., J.S. Blanco, M. Braun, H. Reyes \& N. Silva. 1996a. Chlorophyll- $a$ distribution and associated oceanographic conditions in the upwelling region off northern Chile during the winter and spring 1993. Deep-Sea Research 43: 267-289.

Morales, C.E., M. Braun, H. Reyes, J.L. Blanco \& A. DAvIES. 1996b. Anchovy larval distribution in the coastal zone off northern Chile: the effect of low dissolved oxygen concentration and of a coldwarm sequence 1990-95. Investigaciones Marinas,Valparaíso. 24: 77-96.

OJeda, F.P., F.A. Labra \& A.A. Muñoz. 2000. Biogeographic patterns of Chilean litoral fishes. Revista 
Chilena de Historia Natural 73: 625-641.

PaINe R.T. 1994. Marine rocky shores and community ecology: an experimentalist's perspective: 152 Ecology Institute, Oldendorf/Luhe, Germany.

Palma, S. 1973. Contribución al estudio de los sifonóforos encontrados frente a la costa de Valparaíso. I. Taxonomía. Investigaciones Marinas Valparaíso 4: 17-88.

PaLma, S. 1994. Distribución del macroplancton gelatinoso en un área de desove de peces frente a la costa central de Chile $\left(32^{\circ}-33^{\circ}\right)$. Revista de Biología Marina 29: 23-45.

Palma, S. \& S. Rosales. 1995. Composición, distribución y abundancia estacional del macroplancton de la bahía de Valparaíso. Investigaciones Marinas 23: 49-66.

Peterson, W.T., C.B. Miller \& A. Hutchinson. 1979. Zonation and maintenance of copepod populations in the Oregon upwelling zone. Deep-Sea Research. 26: 467-494.

Peterson, W.T. \& D.C. Bellantoni. 1987. Relationships between water column stratification, phytoplankton cell size and copepod fecundity in Long Island Sound and off central Chile. South African Journal of Marine Sciences 5: 411-421.

Peterson, W., D. Arcos, G. McManus, H. Dam, D. Bellantoni, T. Johnson \& P. Tiselius. 1988. The nearshore zone during coastal upwelling; Daily variability and coupling between primary and secondary production off Central Chile. Progress in Oceanography 20: 1-40.

Pickard, G.L. 1973. Water structure in Chilean Fjords. In: R. Fraser (Ed.), Oceanography of the South Pacific. 1972 New Zealand National Commission UNESCO, Wellington 95-104.

Pickard, G. L. \& W.J. EMERY. 1990. Descriptive physical oceanography. Pergamon Press. Toronto, Canada.

Purvis, A. \& A. Héctor. 2000. Getting the measure of biodiversity. Nature 405: 212-219.

Putman, R. J. 1994. Community Ecology. Chapman \& Hall, London. 177 pp.

Raffaelli, D. \& S. Hawkins. 1996. Intertidal Ecology. Chapman \& Hall, London. 356 pp.

Retamal, M. 1981. Catálodo ilustrado de los crustáceos decápodos de Chile. Gayana, Zoología 44: 1-110.

Rivadeneira, M., M. Fernández \& S. Navarrete. 2002. Latitudinal trends of species diversity in rocky intertidal herbivore assemblages: spatial-scale and the relationship between local and regional species richness. Marine Ecology Progress Series 245: 123-131.

Rohde, K., M. Heap \& D. Heap. 1993. Rapoport's rule does not apply to marine teleosts and cannot explain latitudinal gradients in species richness. American Naturalist 142: 1-16.

Rojas, P., R. Escribano \& V. Marín. 2002. The influence of coastal upwelling on fish larvae distribution off Mejillones Peninsula, northern Chile. Fishery Oceanography 11: 233-244.
Roy, K. 1998. An upwelling-induced retention area off Senegal: A mechanism to link upwelling and retention processes. In: S. Pillar, C. Moloney, A. Payne \& F. Shillington (Eds.), Benguela Dynamics: Impacts of Variability on Shelf Sea Environments and their Living Resourses. South African Journal of Marine Sciences 19: 89-98.

Roy, K., D. JABLONSKI \& J.W. VALENTINE. 1994. Eastern Pacific molluscan provinces and latitudinal diversity gradient: no evidence for "Rapport's rule". Proceedings of the National Academy of Sciences, USA 91: 8871-8874.

Roy, K., D. Jablonski, J. Valentine \& G. Rosenberg. 1998. Marine latitudinal diversity gradients: test of causal hypotheses. Proceedings of the National Academy of Sciences, USA, 95: 3699-3702.

Roy, K., D. Jablonski \& J.W. Valentine. 2000. Dissecting latitudinal diversity gradients: functional groups and clades of marine bivalves. Proceedings of the Royal Society of London, Series b-Biological Sciences 267: 293-299.

SANtelices, B. 1980. Phytogeographic characterization of the temperate coast of Pacific South America. Phycologia 19: 1-12.

Santelices, B. \& P.A. Marquet. 1998. Seaweeds, latitudinal diversity patterns, and rapport's rule. Diversity and Distribution 4: 71-75.

Sherman, K., L.M. AleXANDER \& B.D. Gold (Eds.), 1995. American Association for the Advancement of Science, Washington D.C., pp -53-68.

Sielfeld, W., M. Vargas \& R. Fuenzalida. 1995. Peces mesopelágicos frente a la costa norte de Chile $\left(18^{\circ} 25^{\prime}-21^{\circ} 47^{\prime} \mathrm{S}\right)$. Investigaciones Marinas Valparaíso 23: 83-98.

Strub, P., J. Mesías, V. Montecino \& J. RutLland. 1998. Coastal ocean circulation off western South America. In: A. Robinson \& K. Brink (Eds.), The Sea, Vol. 2. The Global coastal ocean. First Workshop on Coastal Ocean Advanced Science and Technology Studies (COASTS) IOC, Liege. John Wiley \& Sons, Inc.

Summerhayes, C.P.K., C. EmeIs, M.V. Angel, R.L. SMith \& B. ZeITZChel. 1995. Upwelling in the ocean: modern processes and ancient records. In: Summerhayes, C.P., K.-C. Emeis, M.V. Angel, R.L. Smith \& B. Zeitzchel (Eds.), upwelling in the ocean: modern processes and ancient records. pp. 1-38. John Wiley \& Sons.

Ulloa, O., R. Escribano, S. HoRmazÁbal, R. QuiÑonez, M. Ramos \& R. GonzÁLEZ. 2001. Evolution and biological effects of the 1997-98 El Niño in northern Chile. Geophysical Research Letters 28: 1591-1594.

URIBE, J.C. 1992. Fitoplancton en los fiordos magallánicos. In: Gallardo, V.A., O. Ferretti \& H.I. Moyano (Eds.), Oceanografía en Antártica, Proceedings International Seminar Centro EULA/ Universidad de Concepción. Universidad de Concepción, Concepción, Chile, pp. 467-478.

Valdovinos, C., S.A. Navarrete \& P.A. Marquet. 2003. 
Patterns of diversity of Chilean marine ecosystem: EsCRIBANO, R. ET AL.

Mollusk species diversity in the southeastern Pacific: why are there more species towards the pole? Ecography (in press).

Verheye, H.M., L. Hutchings, J.A. Hugget \& S.J. PAINTING. 1992. Mesozooplankton dynamics in the Benguela ecosystem, with emphasis on the herbivorous copepods. In: Payne, A.I.L., K.H. Brink, K.H. Mann, R. Hilborn (Eds.), Benguela Trophic Functioning. South African Journal of Marine Sciences 12: 561-585.

VIDAL, J. 1976. Copépodos calanoideos epipelágicos de la expedición Marchile II. Gayana Zoología 15: $1-98$.

Viviani, E.A. 1979. Ecogeografía del litoral chileno. Studies on neotropical fauna and environment 14: 65-
123.

WALSH, J.J. 1991. Importance of continental margins in the marine biogeochemical cycling of carbon and nitrogen. Nature 350: 53-55.

Wing, S.L., S. Botsford, Ralston \& J. Largier. 1998. Mesoplanktonic distribution and circulation in a coastal retention zone of the northern California upwelling system. Limnology and Oceanography 43: $1710-1721$

Wieters, E. 2000. Marine Macroecology. Trends in Ecology and Evolution 16: 67-69.

WROBLEWSKI, J.S. 1982. Interaction of currents and vertical migration in maintaining Calanus marshallae in the Oregon upwelling zone: a simulation. Deep-Sea Research, 29: 665-686.

Fecha de recepción: 06/05/03

Fecha de aceptación: 10/09/03 